\title{
Gambaran sementoblastoma tahap awal pada cone beam computed tomography (CBCT) 3D: laporan kasus
}

\author{
Rellyca Sola Gracea ${ }^{1 *}$, Ria Noerianingsih Firman² \\ ABSTRACT \\ Objectives: The purpose of this study was to report \\ a case of mandibular cementoblastoma with \\ radiologic approach and describe its characteristics. \\ Case Report: : A 32-year-old female came to the \\ Hospital and complained of swelling of the left side \\ of the lower jaw. Clinical examination showed a \\ strong swelling in the buccal region of teeth 44-45, \\ with the same soft tissue color as the surrounding \\ tissue. In the picture cone beam computed \\ tomography appears as a rounded lesion, the \\ internal structure of the radiointermediet with clear \\ and firm boundaries, surrounded by a halo \\ radiolucent. Cementoblastoma radiodiagnosis is \\ established. The patient was referred for surgery. \\ Conclusion: Cementoblastoma was a benign tumor \\ with radiographic characteristics in the form of \\ clearly demarcated radiopaque lesion with \\ radiolucent halo. Some early-stage lesions can show \\ lower density.
}

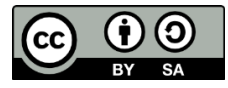

This work is licensed under a Creative Commons Attribution 4.0
${ }^{1}$ Departemen Radiologi Kedokteran Gigi, Fakultas Kedokteran Gigi, Universitas Gadjah Mada, Yogyakarta, Indonesia, 55281

2Departemen Radiologi Kedokteran Gigi, Fakultas Kedokteran Gigi, Universitas Padjadjaran, Bandung, Indonesia, 40132

${ }^{*}$ Correspondence to:

Rellyca Sola Gracea

囚rellycasolagracea@ugm.ac.id

Received on: October 2019 Revised on: December 2019 Accepted on: January 2020

Keywords: Cementoblastoma, odontogenic tumor, CBCT

Cite this article: Gracea RS, Firman RN. Gambaran sementoblastoma tahap awal pada Cone Beam Computed Tomography (CBCT). Jurnal Radiologi Dentomaksilofasial Indonesia 2019;3(2):49-51. https://doi.org/10.32793/jrdi.v3i3.446

\section{PENDAHULUAN}

Sementoblastoma merupakan lesi jinak langka yang mewakili kurang dari $1 \%$ tumor odontogenik. Tumor jinak ini berasal dari ektomesenkim odontogenik. Karakteristik dari tumor ini yaitu berkembang dari jaringan yang menyerupai sementum. ${ }^{1}$ Lesi ini sering ditemukan di mandibula, paling umum pada regio premolar dan molar. ${ }^{2}$

Nyeri dan bengkak merupakan gejala yang biasa dirasakan, namun dapat bersifat asimtomatik dan ditemukan sebagai temuan insidentil saat pemeriksaan rutin. ${ }^{2,3}$ Gigi yang terlibat dengan sementoblastoma menunjukkan tanda vital, namun pada beberapa kasus tahap lanjut ditemukan pada kondisi gigi yang non-vital. ${ }^{4}$

Kondisi ini tidak dapat ditegakkan hanya dari pemeriksaan klinis. Diagnosis final biasanya ditegakkan secara histopatologis, namun diagnosis klinis dapat dilakukan dengan mudah dengan bantuan pemeriksaan radiografi, seperti panoramik dan cone beam computed tomography (CBCT). Sebagian besar kasus sementoblastoma dilaporkan menunjukkan gambaran radiografis berupa gambaran radiopak, tetapi tumor radiolusen dapat muncul dalam jumlah kasus yang jarang. Tindakan bedah enukleasi pada massa merupakan tindakan yang dapat dilakukan. ${ }^{5}$

Laporan kasus ini mendeskripsikan suatu temuan lesi sementoblastoma dengan gambaran radiografis yang jarang ditemui. Lesi melekat pada sisi bukal gigi premolar pertama rahang bawah. Kondisi gambaran radiografis menunjukkan radiointermediet pada hasil pemeriksaan CBCT.

\section{LAPORAN KASUS}

Seorang wanita berusia 32 tahun datang ke RSGM Universitas Padjajaran untuk memeriksakan kondisi rongga mulutnya. Pasien mengeluhkan gusinya membengkak pada daerah rahang bawah kiri yang mulai disadari sejak 3 bulan yang lalu, menurut pengakuan pasien pembengkakan pada gusi tumbuh secara perlahan. Pasien tidak mengeluhkan adanya nyeri spontan maupun saat digunakan untuk mengunyah makanan.

Pemeriksaan klinis menunjukkan adanya pembengkakan keras pada regio bukal gigi 44-45, dengan warna jaringan lunak sama seperti jaringan sekitarnya. Pada gigi 44 dan 45 tidak ditemukan adanya karies, dan pemeriksaan obyektif menunjukkan bahwa gigi tersebut vital. Dokter gigi yang memeriksa mencurigai pasien mengalami osteoma, kemudian pasien dirujuk untuk melakukan pemeriksaan CBCT.

Hasil pemeriksaan CBCT (Gambar 1 \& 2) menunjukkan adanya lesi radiointermediet pada bukal akar gigi 44 berbentuk bulat berbatas jelas dengan dikelilingi halo radiolusen. Lesi tampak berhubungan dengan sementum akar gigi 44 .

Potongan koronal menunjukkan lesi mengalami ekspansi ke bukal dan menyebabkan penipisan tulang kortikal sisi bukal. Untuk memastikan apakah lesi berhubungan dengan sementum gigi maka inverted view diaktifkan pada gambaran koronal CBCT. Inverted view menunjukkan lesi menempel langsung pada akar gigi, tidak tampak adanya ruang ligamen periodontal dan lamina dura yang memisahkan antara lesi dan sementum gigi 
(Gambar 2A). Potongan sagital (Gambar 2B) menunjukkan lesi berbentuk sirkuler dengan ukuran lesi $8,4 \mathrm{~mm} \times 9,5 \mathrm{~mm}$. Pengukuran densitas menunjukkan nilai rata-rata sebesar 372,2 pixel values yang tampak sebagai gambaran radiointermediet. Terdapat halo radiolusen yang mengelilingi lesi. Gambar 2C menunjukkan potongan aksial, tampak lesi mengalami ekspansi ke bukal dan menempel pada akar gigi.

Pemeriksaan klinis dan radiografis mengarah pada diagnosis klinis berupa sementoblastoma. Pasien kemudian dirujuk ke klinik bedah mulut untuk mendapatkan tindakan enukleasi.

\section{DISKUSI}

Sementoblastoma adalah tumor odontogenik yang tumbuh lambat dan jinak, dan ditandai dengan pembentukan jaringan seperti sementum yang berhubungan dengan akar gigi. Kasus sementoblastoma yang dilaporkan lebih banyak ditemui pada wanita dibanding pria. Kelainan in juga lebih sering ditemukan pada mandibula daripada maksila. ${ }^{6}$ Tanda dan gejala klinis dapat muncul sebagai asimtomatik, namun dapat juga muncul sebagai pembengkakan dengan nyeri yang mengganggu pada sisi bukal atau lingual/palatal tulang alveolar. Tes vitalitas pada gigi yang terlibat biasanya menunjukkan hasil positif. Tanda klinis lainnya adalah adanya ekspansi kortikal dan asimetri fasial. ${ }^{4}$

Secara radiografis, sementoblastoma muncul sebagai lesi radiopak berbentuk bulat, berbatas jelas dan dikelilingi halo radiolusen. Salah satu ciri khas yang mungkin tampak adalah sementoblastoma memiliki pola radial pada struktur internalnya menyerupai roda. Beberapa tumor, terutama yang berulang, mungkin benarbenar radiolusen karena mineralisasi yang kurang. ${ }^{3}$ Meskipun sementoblastoma merupakan tumor jinak, namun beberapa kasus dapat menunjukkan sifat agresif seperti destruksi tulang, ekspansi tulang, erosi tulang kortikal, dan displacement gig didekatnya. $^{5}$

Pada kasus didapatkan lesi radiointermedie berbentuk bulat, dengan densitas lebih rendah dari densitas dentin dan tidak tampak adanya pola radial pada struktur internal. Hal ini mungkin disebabkan karena lesi masih dalam tahap awal, sehingga densitas lesi masih tampak rendah. Subramani, et al. menyatakan bahwa spektrum gambaran radiografis dari sementoblastoma tergantung pada derajat mineralisasinya. ${ }^{4} \quad$ Sementoblastoma berkembang dengan gambaran awal lesi radiolusen, kemudian menjadi gambaran radiolusen dan radiopak bercampur, dan lesi matur menunjukkan gambaran radiopak. $^{3}$

Lesi tahap awal menunjukkan gambaran yang lebih radiolusen dan dapat dibedakan dari mineralisasi periapikal, lesi inflamasi periapikal seperti focal sclerosing osteitis dan osteomyelitis. Untuk gambaran lesi pada tahap akhir akan sulit dibedakan dari hipersementosis, cementoosifying fibroma, osteoma, osteoblastoma, odontoma, dan lesi radiopak lainnya. ${ }^{4}$

Pemeriksaan histologis dari sementoblastoma akan menunjukkan jaringan menyerupai sementum dengan banyak garis reversal dan sementoblas yang aktif. ${ }^{5}$ Pada batas lesi, terdapat tepi jaringan ikat yang mengelilingi dan sel kolumnar menyebar dari jaringan yang tidak termineralisasi. Batas tepi lesi ini yang tampak sebagai zona radiolusen pada gambaran radiograf. ${ }^{7}$ Sesuai dengan kasus yang didapatkan, terdapat halo radiolusen pada sekeliling lesi yang merupakan ciri dari sementoblastoma.

Gambaran halo radiolusen tidak hanya ditemukan pada sementoblatoma saja. Beberapa lesi juga menunjukkan gambaran tepi radiolusen, seperti osteoblastoma, periapical cemento-osseous dysplasia, focal cemento-osseous dysplasia, florid cemento-osseous dysplasia, dan odontoma. ${ }^{8}$ Osteoblastoma sendiri memiliki fase maturasi seperti sementoblastoma, yaitu berawal dari lesi radiolusen, kemudian menjadi lesi radiopak dan radiolusen bercampur, dan matur dalam gambaran radiopak. ${ }^{3}$ Secara histopatologis, osteoblastoma juga menunjukkan gambaran yang mirip dengan sementoblastoma. Sementoblastoma dapat dibedakan dari osteoblastoma dengan melihat batas lesi dengan gigi. Lesi sementoblastoma akan terlihat menempel dan fusi pada akar gigi yang terlibat, sedangkan pada osteoblastoma masih tampak adanya celah antara gigi dengan lesi. ${ }^{9}$

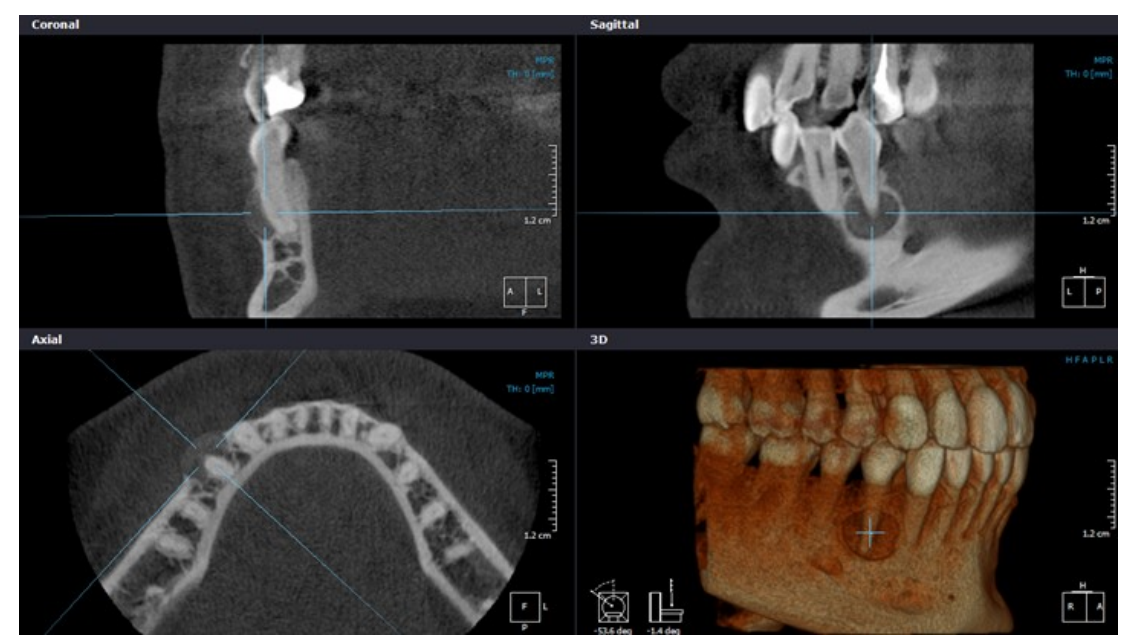

Gambar 1. Tampilan multiplanar reconstruction (MPR) pada regio gigi 44 


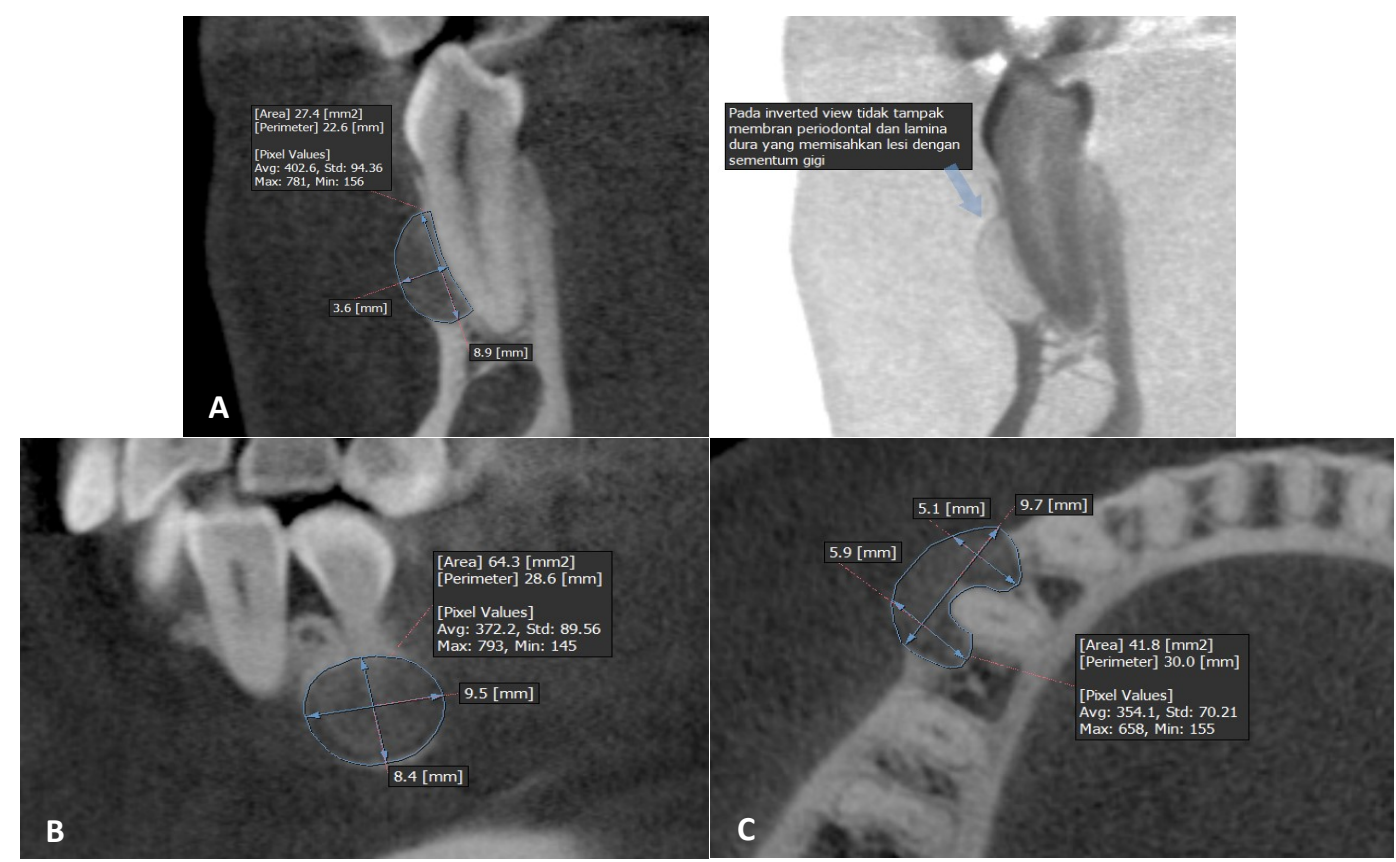

Gambar 2. Tampilan regio gigi 44 dalam pandangan (A) koronal dan koronal inverted-view; (B) sagital; dan (C) aksial

Sementoblastoma termasuk dalam tumor jinak, namun beberapa kasus dilaporkan menunjukkan perkembangan agresif. ${ }^{3}$ Tumor dapat menyebabkan berbagai jumlah resorpsi eksternal, ekspansi tulang, perpindahan gigi yang berdekatan, dan pada beberapa kasus, perforasi kortikal, deformitas rahang, dan fraktur patologis. ${ }^{10}$ Hal ini sesua dengan kasus, dimana lesi tampak mengalam ekspansi ke bukal dan menyebabkan penipisan tulang kortikal bukal. Beberapa kasus dilaporkan bahwa lesi sementoblastoma mengalami rekurensi. ${ }^{4}$ Perawatan yang tepat untuk mencegah rekurensi adalah pengangkatan tumor dengan ekstraksi gigi yang terlibat, kuretasi, dan ostektomi periferal. ${ }^{5}$

Penentuan diagnosis sementoblastoma sangat terbantu dengan adanya pemeriksaan penunjang radiologi. Pemeriksaan radiografi dua dimensi (2D) akan sulit membedakan sementoblastoma dengan lesi lainnya seperti osteoblastoma, terlebih jika lesi masih dalam lesi tahap awal. Kebutuhan radiografi untuk mendukung pemeriksaan dan penegakkan diagnosis mendorong pengembangan teknologi radiografi kedokteran gigi. Kebutuhan akan teknologi yang lebih tepat dan akurat membuat pemeriksaan radiografi tidak hanya terbatas pada gambar 2D seperti periapikal atau panoramik. Sistem pencitraan multiplanar seperti Cone Beam Computed Tomography (CBCT) dapat menjadi pilihan karena dapat menggambarkan detail objek dan mengatasi pencitraan superimposisi citra yang biasa ditemukan pada pencitraan 2D konvensional. Dengan pemeriksaan CBCT, dapat dinilai keterlibatan lesi sementoblastoma terhadap gigi yang terlibat, batas tepi lesi, dan perluasan lesi, sehingga praktisi atau klinisi dapat lebih terbantu dalam menyimpulkan diagnosis sementoblastoma dengan melihat ciri khas pada radiograf.

\section{SIMPULAN}

Sementoblastoma merupakan tumor jinak dengan ciri khas radiografis berupa lesi radiopak berbatas jelas dengan halo radiolusen dan menempel pada gigi yang terlibat. Beberapa lesi tahap awal dapat menunjukkan densitas yang lebih rendah. Pemeriksaan radiografi diperlukan untuk membantu penegakan diagnosis. CBCT dapat menunjukkan detail gambaran dan perluasan lesi dengan baik dibanding radiograf konvensional 2D.

\section{DAFTAR PUSTAKA}

1. Kumar S, Angra R, Prabhakar V. Infected cementoblastoma. Natl J Maxillofac Surg. 2011;2(2):200.

2. Milani CM, Thomé CA, Sayuri $R$, et al. Mandibular cementoblastoma: Case report. Open J Stomatol. 2012;2 (March):50-3.

3. Dogra KS, Sharma A, Sharma N, Sharma A. Cementoblastoma a Rare Odontogenic Tumor -A Case Report and Differential Diagnosis Cementoblastoma a Rare Odontogenic Tumor - A Case Report and Differential Diagnosis. 2016;(September):5-8.

4. Subramani V, Narasimhan M, Ramalingam S, Anandan S, Ranganathan S. Revisiting Cementoblastoma with a Rare Case Presentation. Case Rep Pathol. 2017;2017:1-3.

5. Sharma N. Benign cementoblastoma: A rare case report with review of literature. Contemp Clin Dent. 2014;5(1):92-4.

6. Nuvvula S, Manepalli S, Mohapatra A, Mallineni SK. Cementoblastoma Relating to Right Mandibular Second Primary Molar. Case Rep Dent. 2016;2016(Figure 2):1-5.

7. Huber AR, Folk GS. Cementoblastoma. Head Neck Pathol. 2009;3(2):133-5.

8. Mortazavi $\mathrm{H}$, Baharvand $\mathrm{M}$, Rahmani $\mathrm{S}$, Jafari $\mathrm{S}$, Parvaei $\mathrm{P}$. Radiolucent rim as a possible diagnostic aid for differentiating jaw lesions. Imaging Sci Dent. 2015;45(4):253-261.

9. Sankari LS, Ramakrishnan K. Benign cementoblastoma. J Oral Maxillofac Pathol. 2011;15(3):358-360.

10. White SC, Pharoah MJ. Oral Radiology Principle and Interpretation. 7th ed. Missouri: Elsevier; 2014. 